\title{
ELEPHANT SEAL OIL CARGOES FROM KING ISLAND, BASS STRAIT, 1802-1819: WITH ESTIMATES OF NUMBERS KILLED AND SIZE OF THE ORIGINAL POPULATION
}

\author{
by John K. Ling
}

(with one table, one text-figure, one plate and an appendix)

LiNG, J.K., 1999 (31:x): Elephant seal oil cargoes from King Island, Bass Strait, 1802-1819: with estimates of numbers killed and size of the original population. Pap. Proc. R. Soc. Tasm. 133(1): 51-56. https://doi.org/10.26749/rstpp.133.1.23 ISSN 0080-4703. PO Box 271, Clare, Australia 5453.

Southern elephant seals (Mirounga leonina) were harvested for their oil at King Island, Bass Strait, from 1802 to 1819, by which time they were virtually extinct at that location and have not returned since. Oil cargo statistics have been collated from various secondary sources; in arriving at annual yields, allowance was made for untallied (unquantified) cargoes and a certain amount of waste and onsite use. Depending on the methods of calculation, between 920 and 1326 tons of oil were produced, almost $75 \%$ of this in the first three years and $95 \%$ by 1807 . Some 10000 adult and sub-adult elephant seals would have had to be slaughtered to generate such yields. The approximate total size of the pristine populations is believed to have been between about 10000 and 17000 , based on the various calculated oil yields and a number of fairly broad assumptions.

Key Words: elephant seal oil, King Island, Bass Strait, population size, nineteenth century.

\section{INTRODUCTION}

King Island $\left(40^{\circ} \mathrm{S}, 144^{\circ} \mathrm{E}\right)$ lies at the western end of Bass Strait off the northwestern tip of Tasmania. In October 1801, Governor King, after whom the island was named, instructed Lieutenant James Grant of H.M. Brig Lady Nelson to carry out, inter alia, a survey of the recently discovered island. Grant named a bay on the island the Bay of Elephants (now Sea Elephant Bay), because of the large numbers of sea elephants (southern elephant seals, Mirounga leonina) present on the beaches at that time (Cumpston 1973).

Sealing gangs were quickly dispatched from Sydney to harvest elephant seals for their oil, and fur seals (Arctocephalus spp.) and, to a lesser extent, sea lions (Neophoca cinerea) for their pelts and oil. Cumpston (1973) wrote an excellent account of the early history of the seal oil industry at King Island. Péron, who was the zoologist on Baudin's 18001804 expedition, also described (1816, in Micco 1971) with accompanying illustrations (pl. 1) the elephant seal industry on King Island, which Baudin visited in December 1802. At this time, most breeding adult elephant seals would have left the island, and only new-born pups and moulting immature seals would have occupied the beaches, if the same annual cycle were followed as that described by Carrick et al. (1962b) for Macquarie Island. Péron, however, stated the seals were from 8-10 m in length, so he must have seen very big males, despite the fact that, in view of what we know now (Laws 1953), it would be very unlikely for the largest to have exceeded $6 \mathrm{~m}$ in length.

In the early 19th century, elephant seal oil was regarded as being only slightly inferior to oil of the sperm whale (Physeter macrocephalus). These natural oils were used for illumination - "burning in a bright pure flame without smell or smoke" (Steven 1978) — for lubricating machinery, dressing harness and other leather goods, and ropemaking, and in the manufacture of certain cloths. Seal oil fetched up to $£ 20$ a ton on the London market; therefore, it was an important contributor to Australia's early export income.

It is possible, although no records have been seen, that British and American whaling ships may also have harvested southern elephant seals to supplement their whale oil cargoes, which were taken directly to their home ports.
This account deals only with the colonial industry at King Island.

Southern elephant seals no longer exist on King Island, although stragglers have been reported in Tasmanian, Bass Strait and South Australian waters (Warneke 1982). No other breeding colonies are known to have existed on mainland or Tasmanian coasts or islands. We shall probably never know precisely how many lived and bred on King Island before they were discovered. We can, however, gain some idea of the numbers harvested from the extensive store of information that exists in libraries around the world in the form of shipping records, logs, cargo manifests and newspaper articles of the time; these include numerous references to elephant seal harvests and oil cargoes. Such sources have been searched meticulously by many maritime historians - most notably Cumpston (1968, 1973, 1977), Fowler (1980) and Nicholson (1983) - in the course of compiling their various historical accounts, which have been used for the purpose of this study.

Hindell \& Burton (1988) have already made a very thorough assessment of elephant seal oil harvests at Macquarie Island in the 19th and early 20th centuries, also using only secondary sources of data. They developed a model for quantifying the original elephant seal population on Macquarie Island, by applying modern population parameters, emanating from intensive studies there over many years, to the early harvest figures. No such analysis of the King Island elephant seal oil industry appears to have been attempted; nor will it be here. However, it is possible to derive annual and total oil yields from the secondary sources cited above and make some estimates of how many elephant seals may have supported this industry.

\section{METHODS}

Details of vessel departure and return dates, ports of call and seal product cargoes procured at King Island between 1802 and 1819 were extracted from several secondary sources cited above (appendix 1). Data from each literature source were then collated year by year and, finally, the figures were consolidated into annual and total yields. However, a number 


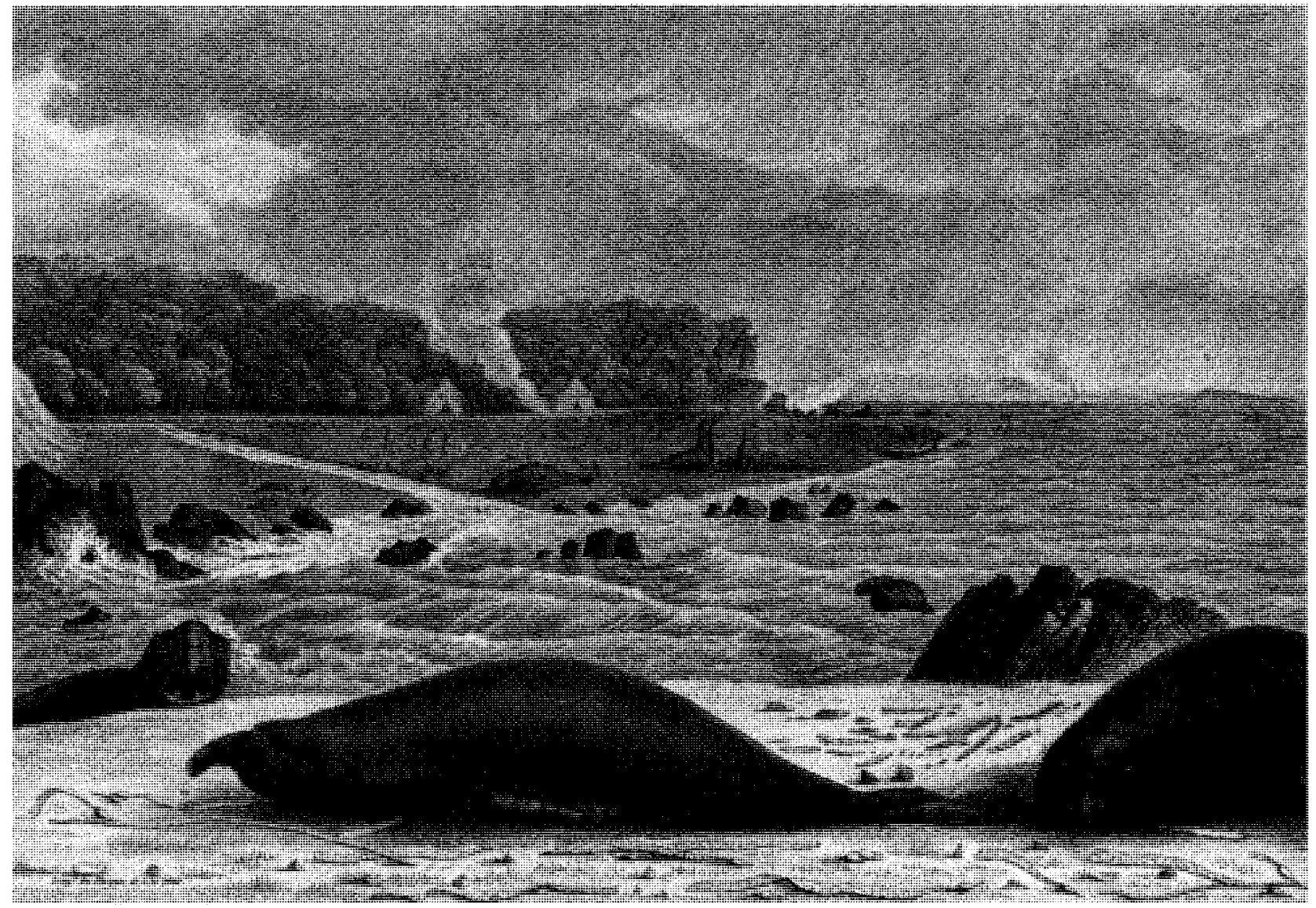

PLATE 1

Engraving by Charles Lesueur of Sea Elephant Bay, King Island, in December 1802, showing the camp of the Baudin expedition scientists, elephant seals, members of a sealing gang on the beach and a whale boat in the surf. Museum d'Historic Naturelle, Le Havre, No. 80007.

of complicating factors in the oil cargo records appeared in various sources consulted during this study; namely:

(1) Cargoes were reported as "elephant oil" (from elephant seals), "seal oil" (from fur seals and sea lions) and simply "oil" (with no indication as to species - and the source will not always help). It is possible that some oil emanating from King Island came from fur seals and sea lions, since oil from these species certainly was obtained at islands in eastern Bass Strait, where elephant seals did not occur. As the last fur seal skins were taken at King Island in 1807 (Ling 1999), any oil shipments after that date may be deemed to have come from elephant seals.

(2) The sealing season tended to be concentrated in the austral summer months when the elephant seals were ashore at varying times according to age and sex (Carrick $e t$ al. 1962b). Therefore, harvesting may have occurred at the end of one year or the beginning of the next. Moreover, some cargoes were shipped months or even years after the oil had been extracted; so again, the times of harvesting are not known precisely.

(3) The terms "Bass Strait" and "Bass's Strait" are used frequently. The latter term sometimes appeared in parentheses after "King(s) Island", but not always, so as to be regarded as a reliable alternative name for King Island. Therefore, only oil stated as having come from King Island is considered here.

(4) Vessels from Sydney visiting King Island often stopped off at islands in eastern Bass Strait on the outward or inward voyage or both. Hence, the exact source or sources of seal products, including oil, is not always clear.

(5) With the presence of both British and American ships in the southwestern Pacific - principally hunting whales imperial and American units of oil measurement may well have been used interchangeably.

(6) Oil cargoes were sometimes expressed as "small quantity" or, simply "oil". It is possible that only small quantities were involved, and more exact tonnages were given for bigger amounts.

Tallied (quantified) cargoes were expressed in several different units of measurement in the literature sources; namely:

Ton/tun - a large barrel, cask or hogshead holding 252 old wine gallons. Four Bordeaux wine casks occupied one ton $\left(=32 \mathrm{ft}^{3}\right)$ of shipping space and held 2016 English pounds weight of 15 ounces to the pound; equal in weight of water to 2000 pounds (Cumpston 1968).

Cask - a wooden barrel of no fixed size; but commonly varying from 42 to 50 gallons capacity. Thus six casks of 42 imperial gallons equalled one ton. (Incidentally, 50 American gallons equal 42 imperial gallons.)

Tierce - a small barrel holding 12 gallons.

Butt - a large barrel holding 96 gallons.

A cask will, for the purpose of this study, be deemed to have contained 42 imperial gallons and a ton to consist of 252 gallons and, since all oil would have been shipped in casks, all cargoes have been converted to tons. 
Untallied (unquantified) cargoes were calculated as the average in any one year, or, in the case of the year 1807, when no other cargoes were listed, as the average of all tallied cargoes, including and excluding the two largest cargoes of 300 tons and 90 tons. This gave rise to "minimum" and "maximum" figures discussed below. A "small quantity" was arbitrarily deemed to be one-tenth of an untallied cargo in a particular year.

Since some oil was used on the island by the sealers for heating, cooking and illumination, and there was doubtless a certain amount of wastage, total figures have been increased by $5 \%$ (following Hindell \& Burton 1988).

\section{RESULTS AND DISCUSSION}

The exploitation of southern elephant seals at King Island was a short-lived affair, lasting only from 1802 to 1819 , with no cargoes being reported for 1808 and 1813 to 1817 (inclusive) in the sources consulted in this study. It is estimated that between 920 tons (tallied) and 1326 tons of oil (tallied plus untallied) were procured during those years, of which about $75 \%$ was obtained in the first three years and $95 \%$ by 1807 . However, because of the difficulties discussed in the Methods section above, it is possible to derive several different total yields of oil.

The very first cargo listed in appendix 1 was 500 gallons (2 tons), but Cumpston (1973: 46) stated that blubber and oil were obtained from 600 elephant seals between February and May 1802, when predominantly sub-adult and adult males would probably have been ashore moulting. He also stated (1973: 46) that one elephant seal (presumably a large male) gave one ton of oil or approximately 250 gallons; elsewhere (1968: 52) he stated that a male elephant seal will yield a third to half a ton ( 80 to 125 gallons). Hindell \& Burton (1988) used figures of 0.2 and 0.07 tons (50 and 17.6 gallons) of oil per male and female respectively, and their figures will be used here. Thus 600 males would have yielded 120 tons of oil and 600 females, 42 tons, with the likely amount being about 100 tons, given the preponderance of large males present at that time.

Two very large shipments of 300 tons in 1803 and 90 tons in 1804 would have increased the averages for the purpose of calculating untallied cargoes in those years; so two sets of figures were derived; one set included these amounts and the other excluded them from the calculations. Taking the above factors into account, the total calculated amount of elephant seal oil shipped from King Island between 1802 and 1819 varied between 920 and 1326 tons, as follows:

920 tons: based only on tallied cargoes listed in appendix 1 , plus the 5\% wastage factor;

1081 tons: based on only 500 gallons ( 2 tons) being landed in May 1802, and untallied cargoes in 1803,1804 and 1807 being calculated with the 300 and 90 tons of 1803 and 1804 , respectively, being excluded, plus the $5 \%$ wastage factor; 1326 tons: based on 600 elephant seals giving 100 tons of oil (see text above) landed in May 1802 and averages for untallied cargoes being calculated with the inclusion of the 300 and 90 tons of 1803 and 1804 , respectively, plus the $5 \%$ wastage factor.

Figure 1 depicts annual "minimum" and "maximum" oil production, based on tallied and untallied cargoes listed in appendix 1 , plus the $5 \%$ wastage factor. The "small quantity" listed for 1804 was arbitrarily taken to be one-tenth of the two other untallied cargoes for that year.

Reported exports of elephant seal oil from King Island to England between 1803 and 1807 amounted to only 448 tons. There are no explanations as to what happened to the remaining quantities of oil, but much of it could have been consumed by the New South Wales colony. There is also no explanation of the source or time of harvesting of 150 tons stated by Fowler (1980) to have been exported in April 1807. In the absence of any explanation, it is assumed that this oil had been obtained and held in storage pending shipment; it is therefore included somewhere in the yearly figures other than 1807 .

The dramatic decline in oil production after 1805 suggests that the elephant seals had already become scarce, through either being depleted in numbers or having been scared away. It is likely that every available large breeding or nonbreeding seal, and possibly every available seal of any size, was taken.

If only breeding adult elephant seals were taken and the sex ratio at King Island was the same as that proposed for Macquarie Island by Carrick \& Ingham (1962b), namely one male to 12 females, and the average oil yield per seal is known, it is possible to convert oil tonnages to seals.

$$
\begin{aligned}
\text { Thus } & \mathrm{T}=\mathrm{M} \times 0.2+\mathrm{F} \times 0.07 \\
\text { where } & \mathrm{T}=\text { tonnage of oil } \\
\mathrm{M} & =\text { number of breeding males } \\
\mathrm{F} & =\text { number of breeding females } \\
\text { if } & \mathrm{F}=12 \mathrm{M} \\
\mathrm{T} & =\mathrm{M} \times 0.2+12 \mathrm{M} \times 0.07 \\
& =1.04 \mathrm{M} \\
\text { therefore } \mathrm{M} & =\mathrm{T} / 1.04 \\
\mathrm{~F} & =12 \mathrm{~T} / 1.04
\end{aligned}
$$

As table 1 - based on the above calculations - shows, 1149 males and 12168 females would be required to produce 1081 tons of oil, and 1800 males and 13800 females to yield 1326 tons.

However, it is most likely that significant quantities of oil were also obtained from large immature elephant seals - if not from any seals that were available at the time. Immature males, aged between four and seven years, increase in length by about $60 \%$ and in weight by about four times, compared with females whose growth flattens out at four years (Carrick et al. 1962a, Ling \& Bryden 1981). Thus, large immature males would certainly have been killed if and when they were present, as they would have been in midsummer. If it were possible to know exactly when each lot of oil was obtained, a knowledge of the southern elephant seal's annual cycle might give some idea of what age or sex group was being exploited at any particular time. Since even the dates of shipment often bore little relationship to when the oil was obtained, it is not possible to guess what category of seals may have contributed to each cargo and, thereby, convert oil quantities to numbers of seals of a particular size.

There is also little information in the literature to indicate the original size of the elephant seal population on King Island. Péron (1816, in Micco 1971: 11) stated that

All the shores of the island are covered with a prodigious number of amphibians, some of which are not less than eight to ten metres long... 


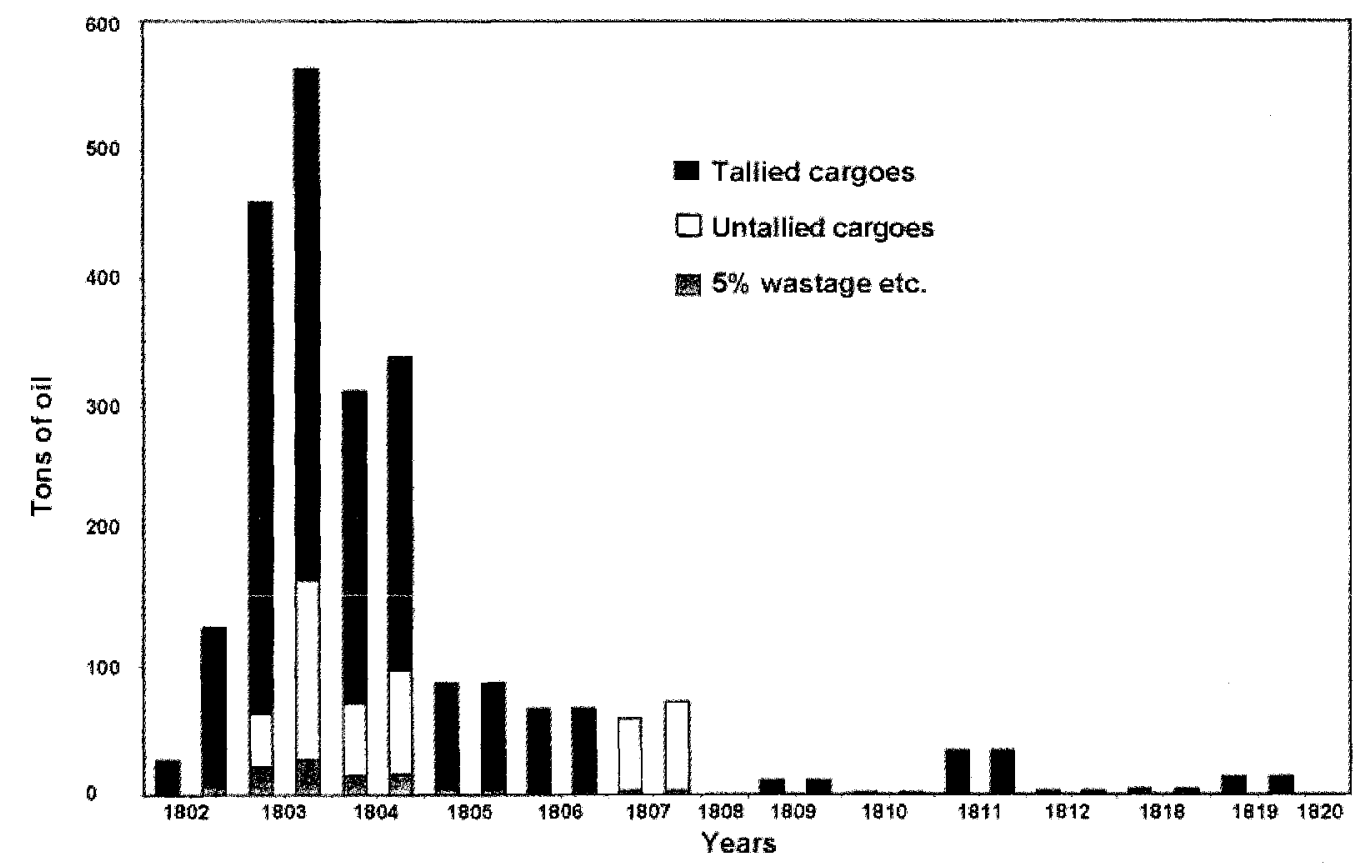

FIG.1 - Minimum (left-hand columns) and maximum (right-hand columns) annual cargoes of elephant seal oil shipped from King Island, 1802-1819; years 1813-1817 omitted (see text for further explanation).

Péron was at King Island from 6-27 December 1802, when mostly immature elephant seals, including quite large (3-4 $\mathrm{m})$ males, would have hauled out to moult (Ling \& Bryden 1981). Some estimate of the total size of the population may be made from notional numbers of breeding males and females that might have been harvested in 1803 to yield 460 and 563 tons of oil - the lower and higher figures as discussed above (table 1). That is

460 tons $=442$ breeding males +5304 breeding females

$$
=5746
$$

563 tons $=541$ breeding males +6492 breeding females $=7033$

Carrick \& Ingham (1962b) arrived at a population of 110000 elephant seals, including pups, at Macquarie Island, based on figures of 36000 adult females and 3500 adult males, which works out to a multiplier factor of 2.78 . Applying this factor to the 1803 figures gives a total population at that time of between 15974 and 19552 It is extremely unlikely, however, that only breeding adults would have been taken; therefore the actual numbers of these age/sex categories would have been less, with an unknown number of immature and sub-adult seals (particularly males) also contributing. Furthermore, as there would probably have been some breeding between 1802 and 1807 - although the population had been severely depleted - three- and four-year-old males would have been available for slaughter. These and sub-adult males would have produced almost as much oil ( 0.2 ton) as a breeding bull; i.e. three times the amount obtainable from an adult female. Thus the total number of breeding adults kilied may have been less by a third to a half than the above figures (table 1) suggest, say 6000 to 8000 ; the total number of seals of all sizes and both sexes killed may have been around 10000 . If, however, as many sub-adult males as breeding males were killed in 1803 , the production figures then become:

460 tons $=884$ males +4043 breeding females $=4927$

563 tons $=1082$ males +4957 breeding females $=6039$
Application of the 2.78 multiplier factor gives a total population in 1803 of between 13697 and 16788 elephant seals. A more accurate figure may be possible using an analysis of catch statistics, measures of effort and modern population parameters that are beyond the scope of this paper.

Hindell \& Burton (1988) used a much more sophisticated model to estimate the size of the original elephant seal population at Macquarie Island, from where 8380 tons of oil had been removed. They arrived at a figure of between 93000 and 110000 animals, which equates to about 11 to 13 seals of all categories per ton of oil. Applying the same factors to the minimum and maximum oil yields from King Island (920 and 1326 tons) suggests a pristine population there ranging from 10120 to 11960 and 14506 to 17238 seals, respectively.

It is clear that elephant seal oil production on King Island declined dramatically after 1804 and had almost ended by 1807 . The population had either been decimated or most of the survivors, particularly breeding animals, had fled. By 1820 , elephant seals were virtually if not actually extinct on the island. Carrick and Ingham (1962a) stated that they had been exterminated in the early part of the 19 th century.

In 1820 , the British Government duty on oil from the colonies was lifted, and it would be surprising indeed if elephant seals were not hunted at King Island for their oil, if they were still there, at least in conjunction with the burgeoning whaling industry. Moreover, draft legislation aimed at liberalising the importation of seal products into Great Britain was to have gone into effect from 1 March 1807 (Steven 1978). Surely, if elephant seals were still present on King Island even at that time, the industry would have continued to prosper until whaling reached its zenith in the 1830 s. 
TABLE 1

Notional numbers of adult male and female elephant seals required to produce minimum and maximum annual yields of oil

\begin{tabular}{|c|c|c|c|c|c|c|}
\hline \multirow[b]{2}{*}{ Year } & \multicolumn{3}{|c|}{ Minimum Yields } & \multicolumn{3}{|c|}{ Maximum Yields } \\
\hline & Tons of oil & Males & Females & Tons of oil & Males & Females \\
\hline 1802 & 27 & 135 & ${ }^{\dagger}(1620)$ & 130 & 650 & ${ }^{\dagger}(7800)$ \\
\hline 1803 & 460 & 442 & 5304 & 563 & 541 & 6492 \\
\hline 1804 & 313 & 301 & 3612 & 339 & 326 & 3912 \\
\hline 1805 & 87 & 84 & 1008 & 87 & 84 & 1008 \\
\hline 1806 & 67 & 64 & 768 & 67 & 64 & 768 \\
\hline 1807 & 59 & 57 & 684 & 72 & 69 & 828 \\
\hline \multicolumn{7}{|l|}{1808} \\
\hline 1809 & 11 & 11 & 132 & 11 & 11 & 132 \\
\hline 1810 & 2 & 2 & 24 & 2 & 2 & 24 \\
\hline 1811 & 34 & 33 & 396 & 34 & 33 & 396 \\
\hline 1812 & 3 & 3 & 36 & 3 & 3 & 36 \\
\hline \multicolumn{7}{|l|}{1813} \\
\hline \multicolumn{7}{|l|}{1814} \\
\hline \multicolumn{7}{|l|}{1815} \\
\hline \multicolumn{7}{|l|}{1816} \\
\hline \multicolumn{7}{|l|}{1817} \\
\hline 1818 & 4 & 4 & 48 & 4 & 4 & 48 \\
\hline 1819 & 14 & 13 & 156 & 14 & 13 & 156 \\
\hline Total & 1081 & 1149 & 12168 & 1326 & 1800 & 13800 \\
\hline
\end{tabular}

* See text for further explanation.

$\dagger$ Equivalent number of breeding females if only adult males contributed the oil in the first year.

\section{ACKNOWLEDGEMENTS}

I thank Mark Hindell and Michael Bryden for their helpful comments on earlier drafts of this manuscript, and my wife, Pauline, for typing it. Figure 1 was prepared by Joanne Goodwin, and plate 1 was kindly provided by $\mathrm{Mme}$ Jacqueline Bonnemains, Curator of the Lesueur Collection of the Museum of Natural History in Le Havre, France. The helpful comments of two anonymous referees are also gratefully acknowledged.

\section{REFERENCES}

CARrick, R. \& Ingham, S.E., 1962a: Studies of the southern elephant seal, Mirounga leonina (L.). I. Introduction to the series. CSIRO Wildl. Res. 7(2): 89-101.

CARrick, R. \& Ingham, S.E., 1962b: Studies of the southern elephant seal, Mirounga leonina (L.). V. Population dynamics and utilization. CSIRO Wildl. Res. 7(2): 198-206.

Carrick, R., Csordas, S.E. \& Ingham, S.E., 1962a: Studies of the southern elephant seal, Mirounga leonina (L.). IV. Breeding and development. CSIRO Wildl. Res. 7(2): 161197.

Carrick, R., Csordas, S.E. \& Ingham, S.E., Keith, K., 1962b: Studies of the southern elephant seal, Mirounga leonina (L.). III. The annual cycle in relation to age and sex. CSIRO Wildl. Res. 7(2): 119-160.

Cumpston, J.S., 1968: Macquarie Island. ANARE Sci. Rep., Ser. A(1) 93: 1-380.

CUMPSTON, J.S., 1973: FIRST VISITORS TO BASS STRAIT. Roebuck, Canberra.

CUMPSTON, J.S., 1977: SHIPPING ARRIVALS AND DEPARTURES, SYDNEY, 1788-1825. Roebuck, Canberra.
FOWLER, R.M., 1980: THE FURNEAUX GROUP, BASS STRAIT. A HISTORY. Vol. 1. Roebuck, Canberra.

Hindeli, M.A. \& Burton, H.R., 1988: The history of the elephant seal industry at Macquarie Island and an estimate of the pre-sealing numbers. Pap. Proc. R. Soc. Tasm. 122(1): $159-176$

Laws, R.M., 1953: The elephant seal (Mirounga leonina Linn.) I. Growth and age. Falk. Is. Dep. Surv. Sci. Reps 8: 1-62.

LiNG, J.K., 1999: Historical harvests of fur seals and sea lions from Australia, New Zealand and adjacent subantarctic islands. Aust. Zool. (in press).

LinG, J.K. \& BRYDEN, M.M., 1981: Southern elephant seal Mirounga leonina Linnaeus 1758. In Ridgway, S.H. \& Harrison R.J. (Eds): HANDBOOK OF MARINE MAMMALS, Vol. 2. Academic Press, London: 297-327.

Mrcco, H.M., 1971: KING ISLAND AND THE SEALING TRADE 1802. A translation of Chapters XXII and XXIII of the narrative by Francois Peron published in the official account of the VOYAGE OF DISCOVERY TO THE SOUTHERN LANDS undertaken in the Corvettes $L e$ Geographe Le Naturaliste and the schooner Casuarina, during the years 1800 to 1804 , under the command of Captain Nicolas Baudin (1816). Roebuck, Canberra.

NICHOLSON, I.H., 1983: SHIPPING ARRIVALS AND DEPARTURES, TASMANIA. Vol. 1. 1803-1833. Roebuck, Canberra.

STEVEn, M.J.E., 1978: Exports other than wool. In Abbott, G.J. \& Nairn, N.B. (Eds): ECONOMIC GROWTH OF AUSTRALIA 1788-1821. Melbourne University Press, Melbourne: 285-305

WARNECKE, R.M., 1982: The distribution and abundance of seals in the Australasian region, with summaries of biology and current research. MAMMALS IN THE SEAS. Vol. 4. FAO Fish. Ser. 5. FAO, Rome: 431-475.

(accepted 5 July 1999) 
APPENDIX 1

Details of elephant seal oil cargoes obtained at King Island: 1802-1819

\begin{tabular}{|c|c|c|c|c|c|c|c|}
\hline Vessel & $\begin{array}{l}\text { Departure } \\
\text { Date }\end{array}$ & $\begin{array}{l}\text { Departure } \\
\text { Port }\end{array}$ & $\begin{array}{l}\text { Arrival } \\
\text { Date }\end{array}$ & $\begin{array}{l}\text { Return } \\
\text { Date }\end{array}$ & $\begin{array}{l}\text { Return } \\
\text { Port }\end{array}$ & $\begin{array}{l}\text { Arrival } \\
\text { Date }\end{array}$ & $\begin{array}{l}\text { Cargo*/ } \\
\text { Remarks }\end{array}$ \\
\hline Harrington & 20.2 .1802 & Sydney & 2.3 .1802 & 27.5 .1802 & Sydney & 31.5 .1802 & $\begin{array}{l}500 \text { gallons } \\
(2 \text { or } 100 \text { tons })^{\dagger}\end{array}$ \\
\hline Margaret & 5.6 .1802 & Sydney & $?$ & 8.7 .1802 & $\begin{array}{l}\text { Norfolk } \\
\text { Island }\end{array}$ & $? .8 .1802$ & $\begin{array}{l}6000 \text { gallons obtained } \\
\quad(24 \text { tons) }\end{array}$ \\
\hline John & 16.6.1803 & Sydney & ?.7.1803 & 12.8 .1803 & Sydney & 5.9 .1803 & 14 tons \\
\hline Surprise & 31.31803 & Sydney & ? & 12.8 .1803 & Sydney & 26.8 .1803 & 700 gallons ( 2.8 tons) \\
\hline Governor King & 10.61803 & Sydney & $?$ & 3.8 .1803 & Sydney & 23.8 .1803 & $\begin{array}{l}21 \text { butts = } \\
2016 \text { gallons ( } 8 \text { tons) }\end{array}$ \\
\hline John & 17.91803 & Sydney & $?$ & $?$ & Sydney & 26.12 .1803 & $\begin{array}{l}\text { "oil" } \\
\text { (66/19 tons, } \mathrm{max} / \mathrm{min})\end{array}$ \\
\hline Governor King & 4.91803 & Sydney & ? & $?$ & Sydney & 16.10 .1803 & 35 tons \\
\hline Endeavour & 18.11 .1803 & Sydney & $?$ & $?$ & Sydney & 17.1 .1804 & $\begin{array}{l}\text { "small quantity" } \\
\text { (6/2 tons, } \max / \mathrm{min})\end{array}$ \\
\hline Edwin & 20.10 .1803 & Sydney & $?$ & $?$ & Sydney & 26.11 .1803 & $\begin{array}{l}\text { "oil" } \\
(66 / 19 \text { tons, } \max / \mathrm{min})\end{array}$ \\
\hline Governor King & 25.10 .1803 & Sydney & $?$ & $?$ & Sydney & 26.12 .1803 & 37 tons \\
\hline Charles & ?1803 & & ? & $?$ & ?USA & ? & 300 tons \\
\hline Governor King & 7.1 .1804 & Sydney & $?$ & $?$ & Sydney & 7.2 .1804 & 39 tons \\
\hline Governor King & 5.4 .1804 & Sydney & ? & $?$ & Sydney & 16.6.1804 & 30 tons \\
\hline Scorpion & ? & Sydney & ? & $?$ & Sydney & 15.9 .1804 & 90 tons $^{\dot{\ddagger}}$ \\
\hline Governor King & $?$ & Sydney & $?$ & $?$ & Sydney & 2.10 .1804 & 33 tons \\
\hline Endeavour & 15.9 .1804 & Sydney & ? & $?$ & Sydney & 30.10 .1804 & 15 tons \\
\hline Nancy & $?$ & Sydney & $?$ & $?$ & Sydney & 14.8 .1804 & "oil" \\
\hline Nancy & 26.8 .1804 & Sydney & $?$ & $?$ & Sydney & 19.10 .1804 & $\begin{array}{l}15 \text { tons }(27 / 19 \text { tons, } \\
\max / \mathrm{min})\end{array}$ \\
\hline Nancy & 6.11 .1804 & Sydncy & $?$ & $?$ & Sydney & 19.12 .1804 & $\begin{array}{l}\text { "oil" (+skins) } \\
\text { (27/19 tons, } \max / \mathrm{min})\end{array}$ \\
\hline Edwin & $? .12 .1803$ & Sydney & $?$ & 27.1 .1804 & Sydney & 8.2 .1804 & $\begin{array}{l}\text { "oil" (+ skins }) \\
(27 / 19 \text { tons, } \max / \mathrm{min})\end{array}$ \\
\hline George & $?$ & Sydney & $?$ & 8.2 .1804 & Sydney & 15.2 .1804 & 6 tons (8 tons) \\
\hline Good Intent & $?$ & Sydney & ? & $?$ & Sydney & 15.3.1804 & $\begin{array}{l}2.5 \text { tons of "oil" } \\
(+ \text { skins })\end{array}$ \\
\hline George & $?$ & Sydney & $?$ & $?$ & Sydney & 29.5 .1804 & 9 tons \\
\hline George & 15.2 .1805 & Sydney & ? & $?$ & Sydney & 17.5 .1804 & 6 tons ( 8 tons) \\
\hline Endeavour & $?$ & Sydney & ? & ? & Sydney & 16.5 .1804 & 13 tons \\
\hline Endeavour & 29.6 .1805 & Sydney & ? & $?$ & Sydney & 22.10 .1804 & $\begin{array}{l}14 \text { tons } \\
(+16 \text { tons left behind })\end{array}$ \\
\hline Governor King & $?$ & Sydney & $?$ & $?$ & Sydney & 13.3.1804 & 34 tons \\
\hline Sophia & $?$ & Sydney & ? & $?$ & $\begin{array}{l}\text { Port } \\
\text { Dalrymple }\end{array}$ & 18.3 .1804 & 64 tons \\
\hline Marcia & $?$ & $\begin{array}{l}\text { Port } \\
\text { Dalrymple }\end{array}$ & $?$ & $?$ & Sydney & 14.2 .1807 & "oil" (+ skins) (28 tons) \\
\hline Governor Hunter & $?$ & Sydney & $?$ & $?$ & $\begin{array}{l}\text { Port } \\
\text { Dalrymple }\end{array}$ & 23.51807 & "oil" (+ skins) (28 tons) \\
\hline Marcia & $?$ & Sydney & $?$ & $?$ & Sydney & 19.3 .1809 & 10 tons \\
\hline Endeavour & $?$ & Sydney & $?$ & $?$ & Sydncy & 3.4 .1810 & 2 tons of "oil" \\
\hline Northumberland & $?$ & Sydney & $?$ & $?$ & Sydney & 4.3 .1811 & 18 tons \\
\hline King George & 6.2 .1811 & Hobart & $?$ & $?$ & Sydney & 23.2 .1811 & 14 tons \\
\hline Brothers & $?$ & $\begin{array}{l}\text { Port } \\
\text { Dalrymple }\end{array}$ & $?$ & $?$ & Sydney & 1.4 .1812 & 3 tons \\
\hline Endeavour & $?$ & King Island & $?$ & $?$ & Sydney & 10.4 .1818 & 4 tons \\
\hline Endeavour & $?$ & King Island & $?$ & $?$ & Sydney & 9.1 .1819 & 13 tons \\
\hline
\end{tabular}

Compiled from Cumpston (1973, 1974, 1977), Fowler (1980), Nicholson (1983) and Steven (1978).

* Originating from King Island, but not always specified in texts as elephant seal oil. Figures in parenthesis are the calculated tonnages for untallied cargocs.

† Cumpston (1973: 46) stated that blubber and oil were from 600 elephant seals, but only 500 gallons (2 tons) were delivered to Sydney.

¥ Stated by Cumpston (1973: 85) to be 94 tons.

$\$$ Cumpston (1973: 82) stated that the George was shortly to be expected with 2000 gallons ( 8 tons) of oil, but ( $p .84$ ) that only 6 tons had been loaded on 8 February. The larger figure $(=8$ tons) has been used in any calculations. 